\title{
Natural regeneration of lodgepole pine in boreal Sweden
}

\author{
Staffan Jacobson (1D) Mats Hannerz
}

Received: 13 November 2019/Accepted: 6 April 2020/Published online: 18 April 2020

(C) The Author(s) 2020

\begin{abstract}
The large-scale introduction of lodgepole pine (Pinus contorta ssp. latifolia, LP) into Swedish forests was initiated around 1970, and currently 520,000 hectares of the forest land are dominated by the species. Even though the tree has mostly serotine cones, adapted to open after forest fires, it has proved able to self-regenerate in Sweden. This study is the first to present, scientifically, the extent of selfregeneration covering the whole current range of LPforests in Sweden. LP-saplings were recorded for three years, 2015-2017, in 8194 subplots distributed over 214 randomly selected LP-stands from latitude $59.6-66.9^{\circ} \mathrm{N}$ and altitude $88-710 \mathrm{~m}$ asl. Of all subplots, $3 \%$ contained LP-saplings, and regeneration was found in $53 \%$ of all stands. The probability of finding LP-saplings was significantly dependent on the plots' distance from the edge of the LP-stand, and 78\% of all saplings were found within and up to $15 \mathrm{~m}$ beyond the stand edge. Most, $63 \%$, of the plots with LP were found on disturbed ground such as wheel tracks, roadsides and where there had been site preparation. The results show that LP can naturally spread under a range of conditions in the studied region. The
\end{abstract}

S. Jacobson $(\square)$

Skogforsk, Uppsala Science Park, 75183 Uppsala,

Sweden

e-mail: staffan.jacobson@skogforsk.se

M. Hannerz

Silvinformation AB, 39359 Kalmar, Sweden

e-mail: mats.hannerz@silvinformation.se regeneration is, however, concentrated in particular stands and should be possible to control with monitoring programmes and measures to eradicate selfdispersed trees in unwanted areas.

Keywords Exotic tree species - Invasiveness - Pinus contorta $\cdot$ Self-dispersal $\cdot$ Self-spreading

\section{Introduction}

Tree species have been spread with human assistance over nation boarders since ancient times, often in small and scattered groups to gardens or parks, but sometimes in order to introduce new trees on a larger scale (Peterken 2001). The motives for the introductions have varied from curiosity to seeking new ornamentals, timber traits, improved growth or adaptation to sites where native species fail or are less productive. In Sweden, lodgepole pine (Pinus contorta ssp. latifolia, here denoted LP) is the most prominent human-assisted introduction. The species was introduced on a trial basis in the 1920s and this was followed by extended provenance trials in the 1960s (Elfving et al. 2001). Based on the promising results, large-scale planting schemes were established in the central and northern parts of Sweden, with a peak in the 1970s and 1980s (Engelmark et al. 2001). Currently, about 520,000 hectares, corresponding to 
$2.3 \%$ of the productive forest land in Sweden, are occupied by LP (stands with $>65 \%$ basal area of the species), and at least 650,000 hectares have more than a 5\% basal area share of the species (Forest Statistics 2018).

The main motives for the introduction was to overcome a predicted shortage of industrial roundwood and an insufficient access to Scots pine regeneration material for harsh conditions (Elfving et al. 2001). Elfving and Norgren (1993) estimated that LP produces $36 \%$ more than Scots pine on similar sites in Sweden, and it also exhibits higher survival during establishment (Ackzell et al. 1994). However, the species suffers more from wind felling and snow damage (Rosvall 1994; Österberg and Näsman 2015) than the native conifers and has been reported to be more susceptible to Gremmeniella abietina at high altitudes (Witzell and Karlman 2000). The latter obstacle has been explained as a function of maladapted provenances (Karlman 2001), and the problem with instability partly to establishment on too fertile sites, peatlands and the former use of "paperpot" containerized seedlings causing twisted roots (Elfving et al. 2001).

Pines generally have a high potential for becoming invasive due to their small seeds, massive and frequent seed crops, short juvenile period, adaptation to wind dispersal and successful regeneration in new environments (Rejmánek and Richardson 1996). Lodgepole pine regenerates easily on disturbed ground, but also better than Scots pine on wet sites, such as bogs and swamps (Engelmark et al. 2001). Reproduction is less successful in closed LP stands (Lotan and Perry 1983). Lodgepole pine competes well in soils with low nutrient and water availability, but also on good soils (Despain 2001). Frost tolerance gives LP the ability to grow at high altitudes and high latitudes (Despain 2001).

In the early stage of the introduction, it was assumed that the risk of self-regeneration was low under the cold conditions and absence of wildfires in Scandinavia. In its native area in western North America, lodgepole pine is adapted to frequent fires, due to serotine cones that need high temperatures to open (Despain 2001). The risk of self-regeneration in Sweden was deemphasized by authors such as Ledgard (1993) and Ericsson (1994). However, LP also produces non-serotine cones, more common on young trees (OECD 2010). Anecdotal observations
Fig. 1 The location of the selected Pinus contorta (LP) stands. Red (filled) symbols are stands where LP saplings were found, yellow symbols are stands with no LP saplings

(von Segebaden 1992; Engelmark 2011) and a number of student theses (Nyström 1988; Edin 2000; Sjödin 2012; Nemer Barbiche 2013) have shown that natural regeneration occurs in Sweden. Today, it is wellestablished among practitioners that LP regenerate naturally, preferentially on disturbed ground such as roadsides or after soil scarification, and there is concern that LP will invade neighbouring landscapes dominated by native conifers (Richardson and Rejmánek 2004). The extent of the self-regeneration has, however, not been quantified on a broader scale in any of the Fennoscandian countries where the species has been planted.

\section{Objectives}

The main aim was to quantify the magnitude of natural regeneration in LP in northern Sweden, and to identify possible effects of stand and site variables on the risk of uncontrolled natural regeneration. The hypotheses tested were: (1) the presence of naturally regenerated seedlings is dependent of the distance to the stand edge; (2) natural regeneration increases with stand age; (3) natural regeneration is more common on wet soil.

\section{Material and methods}

\section{Study material}

A large-scale empirical study of natural regeneration of LP in Sweden was commenced between 2015 and 2017. Altogether 214 stands were randomly selected based on the following criteria: at least $80 \%$ LP by volume, minimum age 25 years, minimum size 3 hectares and at least $240 \mathrm{~m}$ distance from the nearest LP stand. The stands covered the whole area where lodgepole pine has been planted in Sweden, from latitude $59.6^{\circ} \mathrm{N}$ to $66.9^{\circ} \mathrm{N}$ (Fig. 1), and altitude 88-710 $\mathrm{m}$ asl. All stands were selected from databases supplied by the landowners SCA Skog, Bergvik Skog, Holmen Skog and Sveaskog, whose staff also 


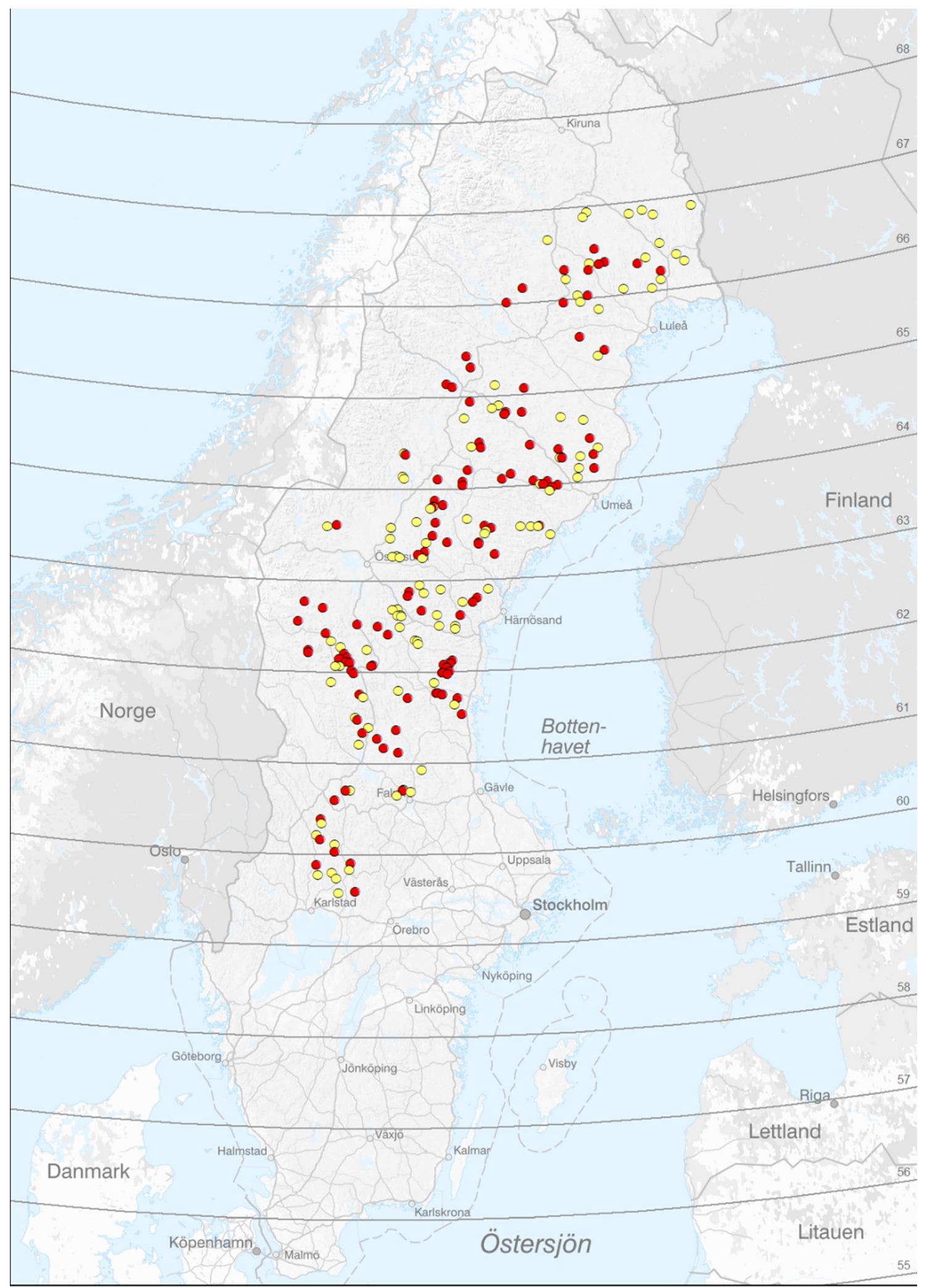


undertook the surveys. The method was calibrated jointly in the field.

In each stand, eight transects were set up, at different points of the compass, originating from the centre of the stand. The presence of naturally regenerated LP seedlings was recorded in six $100 \mathrm{~m}^{2}$ sample plots in each transect, at a fixed distance from the edge of the original LP stand; - 30, 0, 15, 30, 60 and $120 \mathrm{~m}$ respectively. The minimum height of a LP seedling to be recorded was set to $0.5 \mathrm{~m}$. The maximum number of plots in each stand was 48 , but due to restrictions such as plots in lakes or on roads, the average number of plots per stand was 38. In total, the inventory comprised 8194 sample plots (Dataset 1).

A description of possible soil disturbances was recorded individually on all spots where naturally regenerated LP seedlings were found. Descriptive variables for the site and stand were recorded for all sample plots where naturally regenerated LP seedlings were found. In addition, in 32 LP stands $(15 \%$ of all stands), comprising 1,018 plots, the site and stand descriptions were recorded in all plots, i.e. also in plots with LP seedlings absent (Dataset 2).

\section{Statistical analyses}

The probability of finding self-dispersed LP saplings in a plot (binary data; presence or absence) was analysed using a Generalized linear model with binomial distribution of the response variable. We used a logit-link function:

$\operatorname{logit}(p)=\log \frac{p}{1-p}=\mu+s_{\mathrm{i}}+v_{\mathrm{ij}}+e_{\mathrm{ij}}$,

where $p$ is the probability of finding a LP sapling, $\mu$ is the overall mean, $s_{i}$ is the random effect of stand object and $v_{i j}$ are the tested independent variables, alone or in combination, in object $i$ and plot $j$.

Independent variables tested in Dataset 1: latitude, altitude, temperature sum, plot distance from LP stand, age of LP stand, height at the edge of the LP stand and point of the compass of the transect.

Independent variables tested in Dataset 2: land use class, soil type, soil structure, soil moisture class, ground vegetation class (Hägglund and Lundmark 1977), soil depth (cm, in classes), depth of humus layer (cm, in classes), dominant tree species, mean height class of the stand on a plot $(\mathrm{m})$, number of stems in classes $\left(\mathrm{n} \mathrm{ha}^{-1}\right)$, basal area $\left(\mathrm{m}^{2} \mathrm{ha}^{-1}\right)$.
The analyses were conducted using PROC GLIMMIX in SAS (SAS/STAT ${ }^{\circledR} 9.4$ TS Level 1M4, https:// www.sas.com). Statistical significance was defined as $\mathrm{p}<0.05$.

\section{Results}

Overall extent of natural regeneration

Naturally regenerated LP saplings occurred in 113 out of the 214 measured stands (53\%) and in 246 out of 8,194 plots (3\%). The total number of saplings in these plots was 544 (737 if saplings in groups were counted individually). Of all recorded LP saplings, 50\% were found in 20 of the studied stands and $75 \%$ in 40 stands. In plots with recorded LP saplings, the average density was 221 saplings per hectare, and on all plots 6.8 saplings per hectare.

\section{Dataset 1}

The probability of finding naturally regenerated saplings was dependent on the plots' distance from the edge of the LP-stand ( $p<0.01$ in the model). Most of the LP plots were either on the edge or in the nearest buffer zone outside the stand (Fig. 2). About $78 \%$ of the plots with LP saplings were found within and up to $15 \mathrm{~m}$ beyond the stand edge, and $89 \%$ within $30 \mathrm{~m}$. At the furthest distance from the stand edge, $120 \mathrm{~m}, 3.3 \%$ of the plots were found.

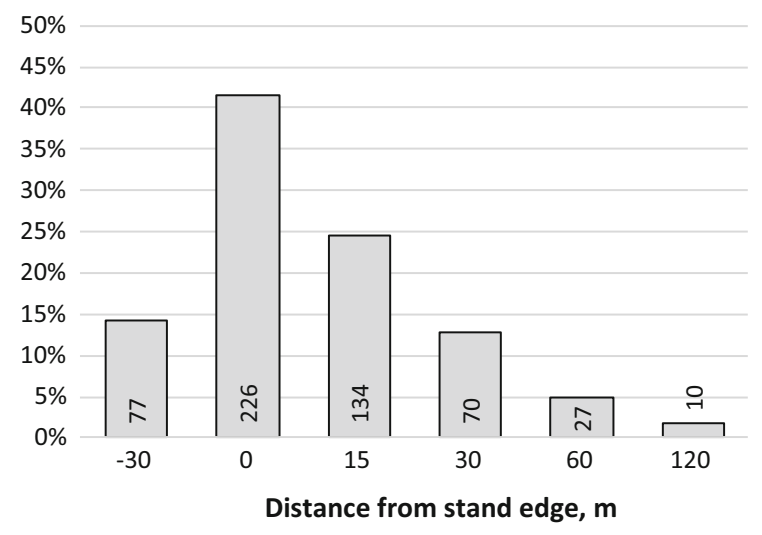

Fig. 2 The number of Pinus contorta saplings, relative to the total number of saplings, distributed at different distances from the stand edge: at the edge $(0)$, inside the stand $(-30)$ and outside the stand at different distances $(15,30,60,120 \mathrm{~m})$. The number of saplings (n) is given for each bar 
The inclusion of latitude in the model was not statistically significant ( $p<0.40$, Fig. 3a). There was a weak tendency towards a higher relative proportion of plots with LP saplings at high altitudes $(\mathrm{p}<0.13)$
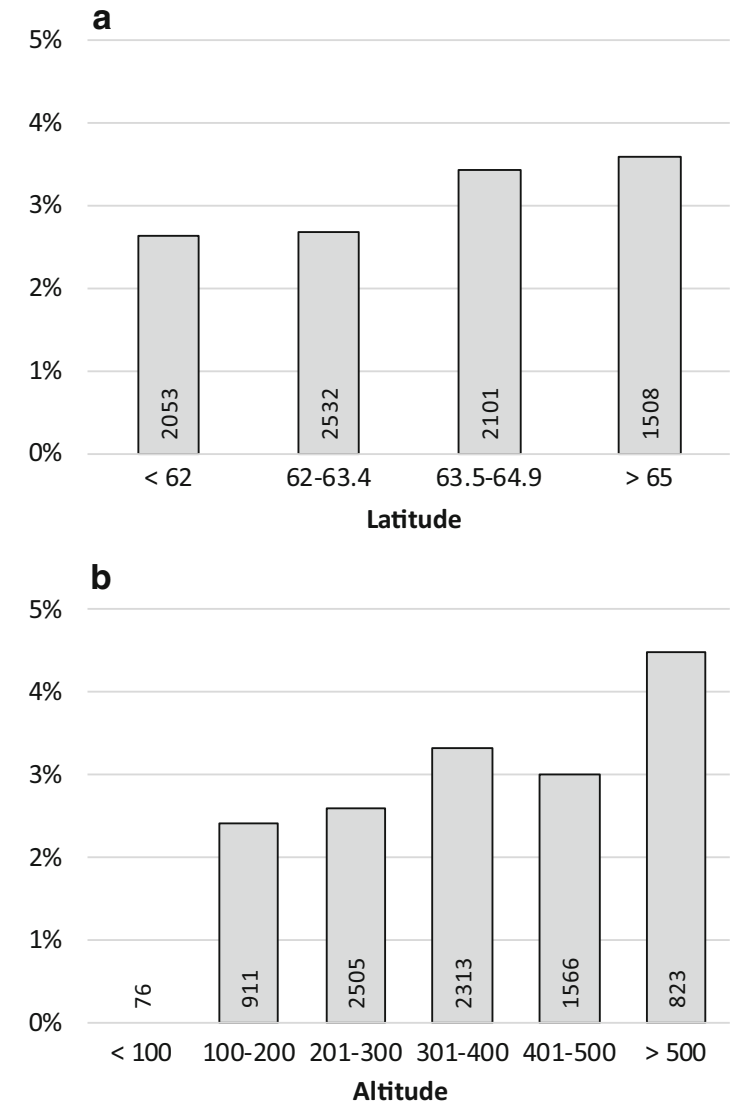

\% C

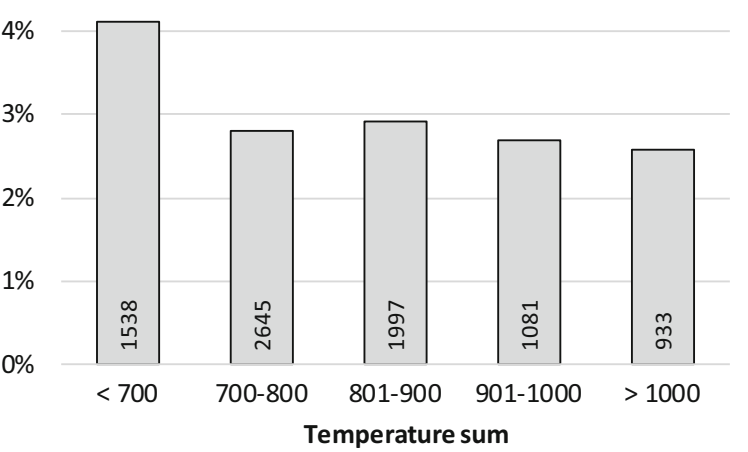

Fig. 3 a-c Proportion of plots with Pinus contorta saplings, in relation to all plots, according to latitude (a), altitude (b) and temperature sum classes (c). The total number of plots (n) in each category class is given for each bar
(Fig. 3b). Analogously, the frequency of plots with LP saplings tended to increase with decreasing temperature sum $(\mathrm{p}<0.08$; Fig. $3 \mathrm{c}$, calculated according to Morén and Perttu 1994).

The inclusion of stand age or stand height (Fig. 4 a-b), as well as point of the compass of the transect (cardinal direction), revealed no patterns $(\mathrm{p}>0.80)$ and did not improve the degree of explanation in the model.

LP saplings were found on both intact, undisturbed soil (37\% of all recorded LP saplings) and disturbed soil, 63\% (Fig. 5). However, since this variable was only registered at the actual spots where naturally regenerated LP seedlings were found, it could not be tested in the linear model used.

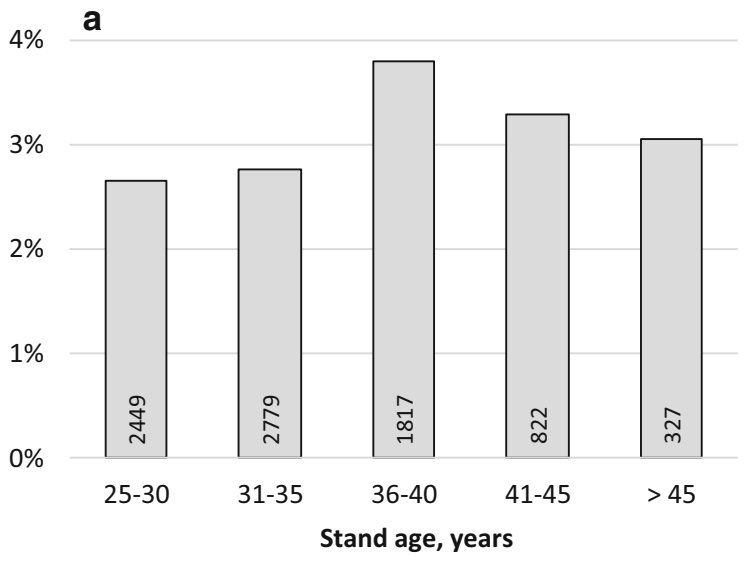

b

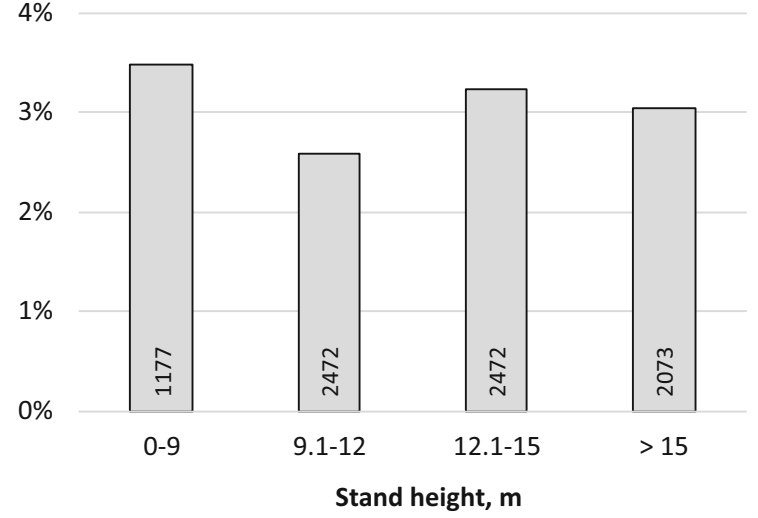

Fig. 4 a, b Proportion of plots with Pinus contorta saplings, in relation to all plots, according to stand age (a) and stand height (b) classes. The total number of plots (n) in each category class is given for each bar 


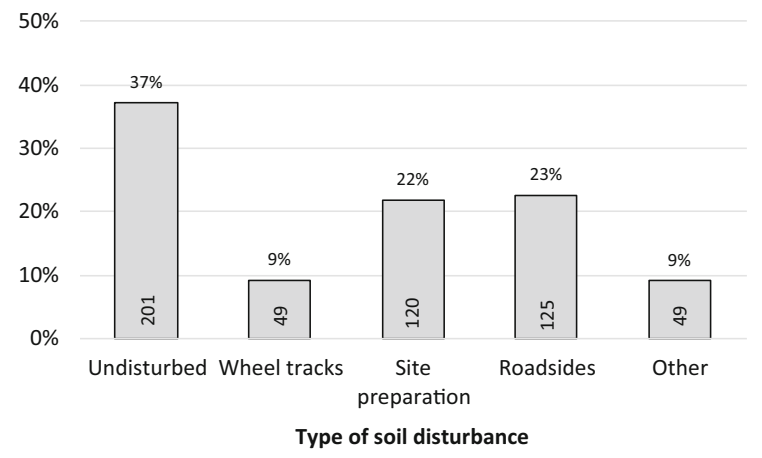

Fig. 5 Relative occurrence of the naturally regenerated Pinus contorta saplings and their distribution in relation to soil disturbance classes (undisturbed soil with intact vegetation, wheel tracks, soil preparation, roadsides and other disturbance). The total number of saplings (n) in each category class is given for each bar

\section{Dataset 2}

This dataset was used to analyse effects of various site and stand characteristics recorded at the plot-level for the 32 stands where both the plots with and without LP-saplings were inventoried. The analysis indicated that the naturally regenerated LP saplings appeared quite randomly in this material. The probability of finding LP saplings was not statistically correlated with any of the tested variables. However, looking at all plots with LP saplings present, there seemed to be an effect of soil moisture class, with less frequent occurrence on moist and wet soil (Fig. 6a) and on open mires (Fig. 6b). This could, however, not be statistically verified, due to the limited number of plots with naturally regenerated LP saplings.

\section{Discussion}

The results show, not surprisingly, that LP has the potential to naturally regenerate in the prevailing conditions in northern Sweden. The magnitude of the natural regeneration is, however, limited. Despite the large data set, only 544 LP saplings were found, with an average density of less than 7 saplings per hectare.

The data also confirmed earlier reports (Nyström 1988; Edin 2000; Sjödin 2012) that natural regeneration occurs at the edge and the $15 \mathrm{~m}$ immediately outside the stand, where $63 \%$ of the plots with LP saplings, and $66 \%$ of all LP saplings were found, thus supporting hypothesis (1), which suggested that the a

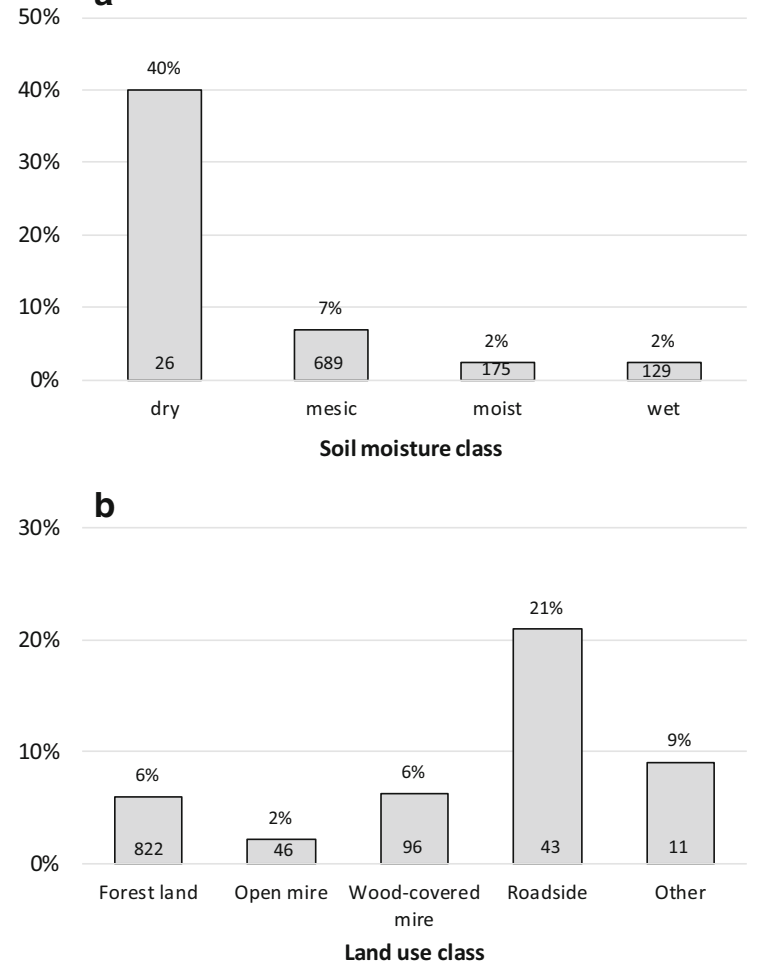

Fig. 6 The relative occurrence of the naturally regenerated Pinus contorta saplings, in relation to all plots where soil moisture was recorded (a), and according to land use classes (b). The total number of saplings (n) in each category class is given for each bar

presence of saplings is dependent on the distance to the stand edge. The magnitude of natural regeneration was also in line with previous results from student theses (Nyström 1988; Sjödin 2012).

The results from the plots with recorded LP saplings indicated that a large proportion $(63 \%)$ were established on disturbed ground, such as wheel tracks and roadsides. However, it must be stressed that old disturbances, such as old scarification plots, can be difficult to identify in the field. Among the 37\% LPplots with no disturbance recorded, some may actually have been disturbed at the time of the seedling establishment. The results, nevertheless, corroborate earlier observations that severe disturbance, such as bare soil along roadsides, is likely to support natural regeneration of LP. Sjödin (2012) found only $14 \%$ of his recorded LP-saplings growing on undisturbed ground, the others on roads, wheel tracks and similarly disturbed plots. 
The effects of stand age were not statistically confirmed in this study, although there was a weak tendency that stands younger than 35 years had a lower proportion of plots with LP saplings. Hence, the results could neither reject nor confirm hypothesis (2), which suggested that natural regeneration increases with stand age. The stands were between 25 and 55 years old, all at an age when seed production can be expected. Lodgepole pine sets cones at an early age: five years has been reported in New Zealand (Ledgard 2001) and 10 years in North America (Schmidt and Alexander 1985; Hannerz et al. 2001). In Sweden, cones have been observed on trees even younger than 10 years, although exceptionally (Jägbrant 2014).

This study could not confirm that natural regeneration on open mires occurs more frequently than on mineral soil. On the contrary, the proportion of plots with LP saplings tended to be lower on moist and wet soils, which are normally more frequent on peatland than on mineral soil. However, spontaneous spread to mires and non-productive land is a risk, and hypothesis (3), which suggested that natural regeneration is more common on wet soils, could not be rejected based on the results of the statistical analyses. Nemer Barbiche (2013) found naturally regenerated LP up to $103 \mathrm{~m}$ away on rocky sites and $136 \mathrm{~m}$ on mires, measured from the planted LP stand.

\section{Ecological effects of self-regeneration}

The environmental effects of the tree species have been reviewed in an environmental assessment (Andersson et al. 1999; Engelmark et al. 2001). Since then, new knowledge has been added, but conclusions from the first report are still mostly valid. Engelmark (2011) discusses LP as a "large-scale ecological experiment". A report from the Swedish Forest Stewardship Council concludes that the risk of natural regeneration is high, but knowledge is limited. Furthermore, the risk to biodiversity is somewhat increased, and actions need to include early pre-commercial thinning, landscape planning and protection zones around sensitive areas (Widenfalk 2015). A doctoral thesis found that LP stands had higher cover of vascular plants than those comprising native tree species and that species richness of epiphytic lichens on LP was comparable with Scots pine (Bäcklund 2016). The conclusion from the thesis was that planting LP "does not create 'green deserts' from the perspective of epiphytic lichens or understory vegetation". Lodgepole pine can also impact soil biota and nutrient cycling, causing shifts in the ectomycorrhizal community (Dickie et al. 2014).

Pinus contorta subsp. latifolia hybridizes and introgresses with jack pine (Pinus banksiana) in both western Alberta and the Northwest Territories in Canada where the two closely related species are sympatric (Critchfield 1980). Lodgepole pine has not been successfully hybridized with pines from any other subsections or continents. Repeated efforts have been made to hybridize Pinus contorta with Pinus sylvestris and other species in subsection Sylvestres, but these have resulted in only empty or non-viable seed (Critchfield, 1980). These strong barriers to hybridization prevent contamination of native pine gene pools in Europe, where Pinus contorta has been widely planted (OECD 2010).

Is lodgepole pine invasive in northern Sweden?

The term "Invasive" has a variety of meanings in the literature. The terminology by Richardson et al. (2000) describes the steps towards invasion, starting with Introduction, when the plant or propagule has been transported by humans across a major geographical barrier. The next step is Naturalization, when the plant has proved able to survive and reproduce. Invasion requires that the plants can spread reproductive offspring to areas distant from the place of introduction, approximately $>100 \mathrm{~m}$ over $<50$ years for species spread by seeds and other propagules.

The framework described by Blackburn et al. (2011) starts with Transport (e.g. trade or unintentional transport), Introduction (capacity for cultivation), Establishment (the species must survive and be able to reproduce in the new environment), Spread and finally Invasion. The steps Transport and Introduction can be controlled with prevention and monitoring, and an Introduced species can theoretically be eradicated. Once established, the species can be controlled to prevent further expansion. If all these measures fail, invasion is a fact, and management must be adapted to mitigate the potential negative consequences.

The European Union (Regulation 1143/2014) has a definition of invasiveness that considers the ecosystem effects: “invasive alien species' means an alien species whose introduction or spread has been found to threaten or adversely impact upon biodiversity and 
related ecosystem services." The definition is also adopted by the Swedish Environmental Protection Agency. Along with the regulation, a list of invasive species has been adopted (European Union 2017). None of the listed species include forest material used in Sweden. Currently, work is in progress to establish a Swedish list of invasive species. In a background material for this work, LP was classified as having "Severe impact" due to its high invasion potential and ecological effects (Strand et al. 2018). Whether LP will be on the national list or not remains to be seen.

We conclude that lodgepole pine is established and naturalized in Sweden. However, the spread from older stands is still slow and the species is mostly regenerating close to the mother trees or stands. The fact that an established tree does not reproduce in the first young stages makes it possible to control with hand pulling or pre-commercial felling if careful control schemes are set up. More severe problems will arise if the species expands into the mountainous areas, mires and nature reserves, locations where operational forestry does not exert "daily control".

In a practical context, possible negative ecological effects of an alien crop must be balanced with the possible gains the crop can deliver. A quarter of the forest plantations throughout the world are composed of introduced species (Dodet and Collet 2012). The exotic tree species represent opportunities for many economic plantation programmes supporting the need for timber, fuel and paper, and to restore degraded lands (Dodet and Collet 2012). The gains from future harvests of planted lodgepole pine stands are also highlighted by the Swedish Forest Agency (Skogsstyrelsen 2018).

\section{Actions to mitigate natural regeneration}

The long initial lag phase and slow dynamics of many exotic forest tree species offer opportunities to control the species while populations are still small (Dodet and Collet 2012). Landscape planning ensuring that the exotic tree species are aggregated can reduce the boundary length and improve the opportunity to control spread outside the plantations (Dodet and Collet 2012). The planted stands can either be surrounded by a closed-canopy native forest where regeneration is limited, or by vegetation that allows regular disturbances that eradicate seeds and seedlings (Dodet and Collet 2012).
Once a species has been spread into a neighbouring ecosystem, three management strategies are possible: eradication (complete elimination), containment (spread restricted to a defined zone) and limitation (species kept at low densities to reduce its negative impact) (van Wilgen et al. 2011).

A prerequisite for control of the possible invasiveness of LP is knowledge about where the stands are located and where the natural regeneration occurs. Regular monitoring around planted stands is thus necessary, and the need will increase as stands age. The landowners offering locations used in this study has control programmes with actions that vary depending on situation (Magnus Andersson, pers. comm.). Naturally regenerated LP is considered a particular problem in areas classified as valuable for biodiversity, on wet sites of medium-high biodiversity value, and in regions where LP is not planted. According to one of the landowners (Magnus Andersson, pers. com.): (i) natural regeneration is routinely recorded when visiting LP-stands prior to silvicultural or logging activities, (ii) all observations of LP saplings are recorded and are followed by cleaning or pre-commercial thinning to remove unwanted saplings, (iii) in mixed forests, where LP grows together with native conifers and deciduous trees, LP will be removed at final felling, if seedlings/saplings are found on mires, these will be uprooted by hand or removed with a brush saw.

Besides the control mechanisms and planned eradication, Widenfalk (2015) suggested a shelter plantation of Scots pine around LP stands. This shelter could reduce the number of cone-bearing LP-trees, which are more common at the edge of a stand. Furthermore, protection zones around biologically valuable areas are recommended (Widenfalk 2015). Such zones are already defined in the Swedish Forest Act (Skogsstyrelsen 2019).

With the intention of encouraging national authorities to implement general principles of prevention and mitigation of the risks posed by invasive alien tree species used in plantation forestry, Brundu and Richardsson (2016) presented a Code of Conduct on Planted Forest and Invasive Alien Trees. This Code comprised 14 principles clustered in five broad groups: (1) Awareness; (2) Prevention and Containment; (3) Early Detection \& Rapid Response; (4) Outreach; (5) Forward Planning. Many of the presented principles are appropriate for Swedish conditions. 
Priorities for future research

The large-scale planting of lodgepole pine in Sweden peaked in the 1980s. Since those stands are now at the age when the seed production can be expected to reach its maximum, it is possible that the natural regeneration will accelerate. It is important to monitor the extent and also to follow up previous studies on how far the species can spread.

The work presented in this study could be extended to include GIS-analysis measuring the proportion of stand and soil types surrounding the planted LP stands. Stands surrounded by mires or rocky unproductive land can be revisited, and surveys can also be undertaken in more distant plots than in the current study.

The extent of natural regeneration of LP in Sweden, i.e. the degree of invasiveness, as well as the understanding of how to limit this spreading, need to be further studied. Parallel to these studies it is of vital importance to continue the environmental research quantifying possible negative effects on biodiversity and ecosystem services. In the end, the benefits of introducing a new tree species must be evaluated against the potential threats and costs posed by this action. The establishment of lodgepole pine in Sweden is one of the most large-scale introductions of exotic tree species in the northern hemisphere and could be further used as an experimental arena for the on-going global research on tree invasions (cf. Richardson et al. 2014).

Acknowledgements The authors wish to thank the landowners SCA Skog, Bergvik Skog, Holmen Skog and Sveaskog who initiated this study and whose staff conducted the field surveys, Gunnar Jansson (Skogforsk) for statistical advice, Jörgen Sjögren (SLU) for valuable discussion and anonymous referees for constructive advice. Financial support for the compilation and analyses of the data, as well as writing this paper, was provided by the Bo Rydin Foundation for Scientific Research.

Open Access This article is licensed under a Creative Commons Attribution 4.0 International License, which permits use, sharing, adaptation, distribution and reproduction in any medium or format, as long as you give appropriate credit to the original author(s) and the source, provide a link to the Creative Commons licence, and indicate if changes were made. The images or other third party material in this article are included in the article's Creative Commons licence, unless indicated otherwise in a credit line to the material. If material is not included in the article's Creative Commons licence and your intended use is not permitted by statutory regulation or exceeds the permitted use, you will need to obtain permission directly from the copyright holder. To view a copy of this licence, visit http://creativecommons.org/licenses/by/4.0/.

\section{References}

Ackzell L, Elfving B, Lindgren D (1994) Occurrence of naturally regenerated and planted main crop plants in plantations in boreal Sweden. For Ecol Manag 65:105-113. https://doi.org/10.1016/0378-1127(94)90162-7

Andersson B, Engelmark O, Rosvall O, Sjöberg K (1999) Miljökonsekvensbeskrivning (MKB) av skogsbruk med contortatall I Sverige [Environmental impact analysis (EIA) concerning lodgepole pine forestry in Sweden]. Skogforsk, Redogörelse No. 1, 1999 (In Swedish with English abstract)

Bäcklund S (2016) The introduction of Pinus contorta in Sweden. Implications for forest diversity. Doctoral Thesis, Swedish University of Agricultural Sciences. Acta Universitatis Agriculturae Sueciae, p 30. ISBN 978-91576-8562-9

Blackburn TM, Pyšek P, Bacher S, Carlton JT, Duncan RP, Jaroš V, Wilson JRU, Richardson DM (2011) A proposed unified framework for biological invasions. Trends Ecol Evol 26(7):333-339. https://doi.org/10.1016/j.tree.2011. 03.023

Brundu G, Richardson DM (2016) Planted forests and invasive alien trees in Europe: a code for managing existing and future plantings to mitigate the risk of negative impacts from invasions. Neobiota 30:5-47. https://doi.org/10.3897/ neobiota.30.7015

Critchfield WB (1980) Genetics of lodgepole pine. Research Paper WO-37. USDA Forest Service, Washington, DC

Despain DG (2001) Dispersal ecology of lodgepole pine (Pinus contorta Dougl.) in its native environment as related to Swedish forestry. For Ecol Manag 141:59-68. https://doi. org/10.1016/S0378-1127(00)00489-8

Dickie IA, St John MG, Yeates GW, Morse CW, Bonner KI, Orwin K, Peltzer DA (2014) Belowground legacies of Pinus contorta invasion and removal result in multiple mechanisms of invasional meltdown. AoB Plants. https:// doi.org/10.1093/aobpla/plu056

Dodet M, Collet C (2012) When should exotic forest plantation tree species be considered as an invasive threat and how should we treat them? Biol Invasions 14:1765-1778. https://doi.org/10.1007/s10530-012-0202-4

Edin M (2000) Contortatallens självspridning i anslutning till planterade bestånd i Norrland [The self-dispersal of lodgepole pine around plantations in northern Sweden]. Master Thesis, Department of Silviculture, Swedish University of Agricultural Sciences (In Swedish with English abstract)

Elfving B, Norgren O (1993) Volume yield superiority of lodgepole pine compared to Scots pine in Sweden. In: Lindgren D (ed) Pinus contorta from untamed forests to domestic crop. Proceedings of of the IUFRO meeting and Frans Kempe symposium 1992 on Pinus contorta provenances and breeding. Report 11, Department of Forest 
Genetics and Plant Physiology, Swedish University of Agricultural Sciences, Umeå, pp. 69-80

Elfving B, Ericsson T, Rosvall O (2001) The introduction of lodgepole pine for wood production in Sweden-a review. For Ecol Manag 141:15-29. https://doi.org/10.1016/ S0378-1127(00)00485-0

Engelmark O (2011) Contortatall i Sverige-ett storskaligt ekologiskt experiment. Sveriges lantbruksuniversitet, Fakta Skog Nr. 9

Engelmark O, Sjöberg K, Andersson B, Rosvall O, Ågren GI, Baker WL, Barklund P, Björkman C, Despain DG, Elfving B, Ennos RA, Karlman M, Knecht MF, Knight DH, Ledgard NJ, Lindelöw $\AA$, Nilsson C, Peterken GF, Sörlin S, Sykes MT (2001) Ecological effects and management aspects of an exotic tree species: the case of lodgepole pine in Sweden. For Ecol Manag 141:3-13. https://doi.org/10. 1016/S0378-1127(00)00498-9

Ericsson T (1994) Lodgepole pine (Pinus contorta var. latifolia) breeding in Sweden-results and prospects based on early evaluations. PhD Thesis, Department of Forest Genetics and Plant Physiology, Swedish University of Agricultural Sciences, Umeå

European Union (2017) Invasive alien species of Union concern. https://ec.europa.eu/environment/nature/pdf/IAS_ brochure_species.pdf

Forest Statistics (2018) Official Statistics of Sweden. Swedish University of Agricultural Sciences, Umeå

Hägglund B, Lundmark J-E (1977) Site index estimation by means of site properties-scots pine and Norway spruce in Sweden. Studia Forestalia Suecica No. 138, Uppsala. ISBN 91-38-03737-8

Hannerz M, Aitken SN, Ericsson T, Ying C (2001) Inheritance of strobili production and genetic correlation with growth in lodgepole pine. For Genet 8:323-329

Jägbrant R (2014) Hur mycket frö sprids från Pinus contorta? Kottproduktion, serotinitet och frökvalitet i relation i relation till beståndsålder i södra Norrland [How much seed is dispersed from Pinus contorta in Sweden? Cone production, serotinity and seed quality in relation to stand age]. Master Thesis, Department of forest ecology and silviculture, Swedish University of Agricultural Sciences (In Swedish with English abstract)

Karlman M (2001) Risks associated with the introduction of Pinus contorta in northern Sweden with respect to pathogens. For Ecol Manag 141:97-105. https://doi.org/10. 1016/S0378-1127(00)00492-8

Ledgard N (1993) A review of research and management of natural regeneration of introduced Lodgepole pine (Pinus contorta Dougl.) with particular emphasis on its unwanted spread in New Zealand. In: Lindgren D. (ed.), Pinus contorta-from untamed forest to domestic crop. Proceedings of the IUFRO Workshop WP 2.02.06 and Frans Kempe symposium, Umeå, Sweden, 24-28 August 1992. Department of Forest Genetics and Plant Physiology, Swedish University of Agricultural Sciences Report No. 11, pp 388-406

Ledgard N (2001) The spread of lodgepole pine (Pinus contorta, Dougl.) in New Zealand. For Ecol Manag 141:43-57. https://doi.org/10.1016/S0378-1127(00)00488-6
Lotan JE, Perry DA (1983) Ecology and regeneration of lodgepole pine. Agriculture Handbook No. 606. United States Forest Service, Washington, DC

Morén A-S, Perttu KL (1994) Regional temperature and radiation indices and their adjustment to horizontal and inclined forest land. Studia Forestalia Suecica No. 194, Uppsala

Nemer Barbiche J (2013) Självspridning av contortatall (Pinus contorta) på impedimentmark i Sverige [Self-spreading of lodgepole pine on unproductive land in Sweden]. Sveriges lantbruksuniversitet, Examensarbeten, 12. Institutionen för skogens ekologi och skötsel (In Swedish with English abstract)

Nyström B (1988) Spontan självföryngring i norrländska contortaplanteringar. Examensarbete i skogsskötsel, Skogsmästarskolan, Skinnskatteberg (In Swedish)

OECD (2010) "Section 5-lodgepole pine (Pinus contorta). In Safety assessment of transgenic organisms, vol 3. OECD Consensus Documents, OECD, Paris

Österberg, T, Näsman M (2015) Windthrow and snow damage at stand level in lodgepole pine compared to domestic species in northern Sweden-future production of lodgepole pine. Bachelor Degree in Forest Science, p 29

Peña E, Hidalgo M, Langdon B, Pauchard A (2008) Patterns of spread of Pinus contorta Dougl. Ex Loud. invasion in a natural reserve in southern South America. For Ecol Manag 256:1049-1054. https://doi.org/10.1016/j.foreco.2008.06. 020

Peterken GF (2001) Ecological effects of introduced tree species in Britain. For Ecol Manag 141:31-42. https://doi.org/10. 1016/S0378-1127(00)00487-4

Rejmánek M, Richardson DM (1996) What attributes make some plant species more invasive? Ecology 77:1655-1661. https://doi.org/10.2307/2265768

Richardson DM, Hui C, Nunez M, Pauchard A (2014) Tree invasions: patterns, processes, challenges and opportunities. Biol Invasions 16:473-481. https://doi.org/10.1007/ s10530-013-0606-9

Richardson DM, Pyšek P, Rejmánek M, Barbour MG, Panett FD, West CJ (2000) Naturalization and invasion of alien plants: concepts and definitions. Divers Distrib 6:93-107. https://doi.org/10.1046/j.1472-4642.2000.00083.x

Richardson DM, Rejmánek M (2004) Invasive conifers: a global survey and predictive framework. Divers Distrib 10:321-331

Rosvall O (1994) Stability in lodgepole pine and resistance to wind and snow loads. Skogforsk, Redogörelse No, p 2

Schmidt WC, Alexander RR (1985) Strategies for managing lodgepole pine. In: Baumgartner et al (eds) Proceedings of the symposium lodgepole pine: the species and its management, 14-16 May 1985, Vancouver, Canada. Washington State University, Pullman, pp 201-210

Sjödin J (2012) Undersökning av självspridning av contortatallen i norra Sverige [A review of self regeneration of lodgepole pine in northern Sweden]. Sveriges lantbruksuniversitet, Examensarbeten, 13. Institutionen för skogens ekologi och skötsel (In Swedish with English abstract)

Skogsstyrelsen (2018) Föreskrifter för anläggning av skog. Regeringsuppdrag. Skogsstyrelsen Rapport 2018/13

Skogsstyrelsen (2019) Skogsvårdslagstiftningen. Gällande regler 1 april 2019 [The Forestry Act] 
Strand M, Aronsson M, Svensson M (2018) Klassificering av främmande arters effekter på biologisk mångfald i Sverige-ArtDatabankens risklista. ArtDatabanken Rapporterar 21. ArtDatabanken SLU, Uppsala

van Wilgen BW, Dyer C, Hoffmann JH, Ivey P, le Maitre DC, Moore JL, Richardson DM, Rouget M, Wannenburgh A, Wilson JRU (2011) National-scale strategic approaches for managing introduced plants: insights from Australian acacias in South Africa. Divers Distrib 17:1060-1075. https://doi.org/10.1111/j.1472-4642.2011.00785.x

von Segebaden G (ed) (1992) Contortatallen i Sverige-en lägesrapport. Skogsstyrelsen, Umeå
Widenfalk O (2015) Contortatall i Sverige. En kunskapssammanställning och riskbedömning. Forest Stewardship Council, Rapport Svenska FSC

Witzell J, Karlman M (2000) Importance of site type and tree species on disease incidence of Gremmeniella abietina in areas with a harsh climate in northern Sweden. Scand J For Res 15:202-209. https://doi.org/10.1080/0282758007500 15019

Publisher's Note Springer Nature remains neutral with regard to jurisdictional claims in published maps and institutional affiliations. 